\title{
Folate deficiency during pregnancy impacts on methyl metabolism without affecting global DNA methylation in the rat fetus
}

\author{
Christopher A. Maloney, Susan M. Hay and William D. Rees* \\ The Rowett Research Institute, Greenburn Road, Bucksburn, Aberdeen, AB21 9SB, UK \\ (Received 15 September 2006 - Revised 4 December 2006 - Accepted 6 December 2006)
}

\begin{abstract}
The methionine cycle and methyl group metabolism are implicated in the long-term programming of metabolism. Diets deficient in folic acid, methionine and choline have been fed to pregnant rats to examine the effects on amino acid metabolism, choline reserves and DNA methylation in dam and fetuses. Animals were fed folate-deficient, folate-deficient with low methionine, folate-deficient with low choline and folate-deficient, low-methionine, low-choline diets starting 2 weeks before mating. The dams and their fetuses were subsequently killed on day 21 of gestation for analysis. Diets low in methionine reduced fetal and maternal weight. Folate deficiency increased the concentrations of homocysteine, glycine, serine and threonine in the maternal plasma, and this was exacerbated by the low-methionine diets. The changes in the amino acid profile in the fetal serum were similar but less pronounced. This result suggests that fetal metabolism was less perturbed. Folate deficiency increased free choline in the maternal liver at the expense of phosphocholine stores. It has been suggested that a deficiency in methyl donors in the diet during pregnancy may impact on key methylation reactions, including the methylation of DNA. Despite widespread changes in the metabolism of choline and amino acids, there was no change in the global methylation of cytosine in DNA from either maternal or fetal livers. This suggests a more indirect mechanism in which gene-nutrient interactions modify the process of differential methylation during development
\end{abstract}

Methionine: Choline: Folic acid: Glycine: Serine: Threonine

Studies in rodents have implicated the methionine cycle and methyl group metabolism in the long-term programming of hypertension and metabolism (Brawley et al. 2004; Lillycrop et al. 2005). The offspring of laboratory rats fed diets containing $8-9 \%(\mathrm{w} / \mathrm{w})$ protein content have increased blood pressure (Langley-Evans et al. 1996) and altered glucose metabolism (Rees et al. 2006) compared with the offspring of dams fed diets containing $18 \%$ (w/w) protein. Supplementing the low-protein diet with folate (Torrens et al. 2006) or glycine (Jackson et al. 2002; Brawley et al. 2004) reverses the adverse effects of protein restriction. As both folic acid and glycine are essential factors in the methionine cycle, these experiments suggest that this pathway has a central role in early-life programming.

A variety of molecules can donate methyl groups to the methionine cycle (Fig. 1), enabling the animal to respond to fluctuations in the diet. Thus, the availability of methionine, glycine, serine and choline must be taken into account when assessing the role of folic acid. In the rat, dietary choline is the major source of methyl groups (Zeisel, 2006). Although choline metabolism is intimately linked with the methionine cycle, little is known about how the balance of methyl donors in the diet impacts on choline (and its main storage form phosphocholine) in the pregnant animal. Furthermore, there is little information on how the availability of folic acid and choline in the diet affects circulating amino acids in the pregnant animal.

A perturbation of the methionine cycle is associated with elevated plasma levels of homocysteine. This is believed to be secondary to changes in intracellular concentrations of S-adenosyl methionine and S-adenosyl homocysteine. High-affinity binding of S-adenosyl homocysteine to the active site of DNA methyltransferase results in product inhibition of the enzyme (James et al. 2002; Hoffman et al. 1980). Since methylation of cytosine residues in the regulatory regions can affect gene activity, any reduction in DNA methylation may adversely affect fetal development (Waterland \& Garza, 1999).

Previous studies have suggested that global DNA methylation is changed in models of programming (Rees et al. 2000; MacLennan et al. 2004). Furthermore a number of studies have suggested that diet or metabolic defects that influence S-adenosyl methionine and/or homocysteine may alter total methylation (Caudill et al. 2001; Choumenkovitch et al. 2002). The present study was carried out to assess the impact of diets deficient in folic acid, methionine and choline on global DNA methylation in the pregnant rat. In the present paper, we report the effects of diets that contained no folic acid (folate deficient, $-F$ ) or that were folate deficient with low methionine ( - F LM), folate deficient with low choline ( - F LC) and folate deficient with low methionine and low

\footnotetext{
Abbreviations: - F, folate deficient; - F LC, folate deficient with low choline; - F LM, folate deficient with low methionine; - F LM LC, folate deficient, low methionine, low choline; SHMT, serine hydroxymethyl transferase.

* Corresponding author: Dr William D. Rees, fax +44 (0) 1224 716622, email w.rees@ rowett.ac.uk
} 


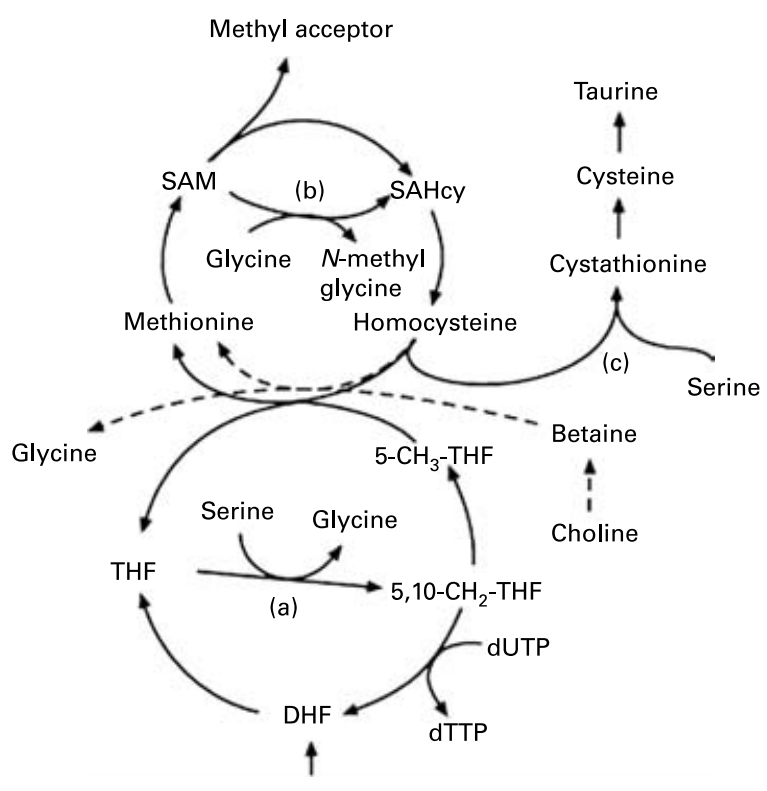

Folic acid

Fig. 1. The metabolic pathways connecting the metabolism of methionine, folic acid and choline. SAM, S-adenosyl methionine; SAHcy, S-adenosyl homocysteine; 5- $\mathrm{CH}_{3}$-THF, methyl tetrahyrofolate; $5,10-\mathrm{CH}_{2}-\mathrm{THF}$, methylene tetrahydrofolate; DHF, dihydrofolate; THF, tetrahydrofolate. (a) serine hydroxymethyl transferase; (b) glycine $\mathrm{N}$-methyl transferase; (c) cystathionine synthase.

choline ( - F LM LC) on amino acid concentrations, choline metabolism and DNA methylation on day 21 of gestation in the rat.

\section{Methods}

\section{Experimental diets}

The experimental diets (Table 1) were based on the AIN-76 formula, which recommends a protein content of $18 \%(\mathrm{w} / \mathrm{w})$ for rodents during gestation and lactation (Bieri et al., 1977). This was achieved by supplementing diets containing $90 \mathrm{~g}$ casein $/ \mathrm{kg}$ diet with a mixture of synthetic amino acids equivalent to an additional $90 \mathrm{~g}$ casein. Methionine was omitted from the amino acid mixture to produce low-methionine diets containing $2.3 \mathrm{mg}$ methionine $/ \mathrm{kg}$ diet compared with $5.6 \mathrm{mg}$ methionine $/ \mathrm{kg}$ diet in the control diet.

\section{Animals}

All experimental procedures were approved by the ethical review committee of the Rowett Research Institute and conducted in accordance with the UK Animals (Scientific Procedures) Act, 1986. Female rats of the Rowett Hooded strain bred in the Institute were allocated to five matched groups of eight animals. The animals were approximately 8-10 weeks of age at the start of the experiment with a mean body weight of $208 \mathrm{~g}$. There were no significant differences between the weights of animals in the different treatment groups when the experiment commenced. Animals were housed on sawdust bedding, and no steps were taken to prevent coprophagy.
Table 1. Composition of the experimental diets

\begin{tabular}{lccccc}
\hline Component (g/kg) & Control & $-\mathrm{F}$ & $-\mathrm{F} \mathrm{LM}$ & $-\mathrm{F} \mathrm{LC}$ & - FLMLC \\
\hline Casein & 90 & 90 & 90 & 90 & 90 \\
Amino acid mix & 90 & 90 & 90 & 90 & 90 \\
Sucrose & 193 & $193 \cdot 2$ & $193 \cdot 2$ & $193 \cdot 2$ & $193 \cdot 2$ \\
Cellulose fibre & 50 & 50 & 50 & 50 & 50 \\
Cornstarch & 425 & 425 & 425 & 425 & 425 \\
Vitamin Mix & 10 & 10 & 10 & 10 & 10 \\
AlN93 - Folate† & & & & & \\
Mineral Mix AIN-93 & 35 & 35 & 35 & 35 & 35 \\
Maize oil & 100 & 100 & 100 & 100 & 100 \\
Choline chloride & 2 & 2 & 2 & 1 & 1 \\
L-Methionineł & $3 \cdot 3$ & $3 \cdot 3$ & - & $3 \cdot 3$ & - \\
Folic acid/sucrose & $0 \cdot 2$ & - & - & - & - \\
mix§ & & & & & \\
$\mathrm{KH}_{2} \mathrm{PO}_{4}$ & $2 \cdot 8$ & $2 \cdot 8$ & $2 \cdot 8$ & $2 \cdot 8$ & $2 \cdot 8$ \\
\hline
\end{tabular}

Casein supplied by Fiske (Milton Keynes, UK), amino acids by Spodefell Ltd (London, UK), sucrose by Craig Group (Catering \& Marine) Services (Aberdeen, UK), cellulose fibre and cornstarch by Special Diet Services (Witham, Essex, UK), vitamin mix components by ICN Biomedicals (Basingstoke, Hampshire, UK) and Sigma (Poole, Dorset, UK), mineral mix per the American Institute of Nutrition (AIN-93G; ICN Biomedicals, Basingstoke, Hampshire, UK), maize oil by Mazola (Princes Ltd, Liverpool, UK), choline chloride and methionine by Sigma and $\mathrm{KH}_{2} \mathrm{PO}_{4}$ by Riedel-de-Haen (now part of Sigma).

$-\mathrm{F}$, folate deficient; - F LM, folate deficient with low methionine; $-\mathrm{F}$ LC, folate deficient with low choline; -F LM LC, folate deficient, low methionine, low choline.

${ }^{*}$ Amino acid mix $(\mathrm{g} / \mathrm{kg}$ ): alanine $26 \cdot 2$, arginine $36 \cdot 9$, aspartic acid $67 \cdot 2$, glutamic acid $97 \cdot 4$, glutamine $97 \cdot 4$, glycine $16 \cdot 0$, histidine $26 \cdot 1$, isoleucine $46 \cdot 3$, leucine 84.0 , lysine 80.8 , phenylalanine $46 \cdot 2$, proline 84.3 , serine $46 \cdot 9$, threonine 36.4 , tryptophan $11 \cdot 7$, tyrosine $51 \cdot 2$, valine $56 \cdot 8$.

† Vitamin Mix AIN-93 - Folate (g/kg): nicotinic acid 3.0, D-Ca pantothenate 1.6, pyridoxine hydrochloride 0.7 , thiamine hydrochloride 0.6 , riboflavin 0.6 , D-biotin 0.02 , vitamin $\mathrm{B}_{12}(0.1 \%$ triturated in mannitol) $2.5, \alpha$-tocopherol powder $(250 \mathrm{U} / \mathrm{g}) 30.0$, vitamin $A$ palmitate $(250000 \mathrm{U} / \mathrm{g}) 1.6$, vitamin $D_{3}(400000 \mathrm{U} / \mathrm{g}) 0.25$, phylloquinone 0.08 , sucrose 959.7 .

$\mp$ As the amino acid mix did not contain L-methionine, $2.3 \mathrm{~g} / \mathrm{kg}$ was added to the control, $-\mathrm{F}$ and $-\mathrm{F}$ LC diets so that their total methionine content was comparable to that of a diet containing $18 \%$ casein $(\mathrm{w} / \mathrm{w})$.

§ Folic acid/sucrose mix (10 mg/g): folic acid 10, sucrose 990.

Five groups of animals were fed control, $-\mathrm{F},-\mathrm{F}$ LM, - F LC or - F LM LC diets. The animals were offered the experimental diets for a 2 -week adaptation period and were then mated with males of the same strain. The day on which a vaginal plug was detected was denoted as day 0 . The female rats were maintained on their corresponding diets until they were killed on day 21 of gestation.

\section{Sample collection and analysis}

Animals were anaesthetised by halothane inhalation and killed by decapitation. The fetuses were rapidly removed, weighed and killed by decapitation. Maternal tissues together with organs from six fetuses, chosen at random from each dam, were rapidly dissected and weighed. Tissues were frozen in liquid $\mathrm{N}$ as soon as possible and subsequently stored at $-70^{\circ} \mathrm{C}$ until required.

\section{Amino acid analysis}

Serum samples were analysed with a Waters Pico-Tag system (Waters Corp., Milford, MA, USA). Phenylisothiocyanate derivatives were separated on a C18 column using a $70 \mathrm{~mm}$ gradient of sodium acetate-acetonitrile buffer ( $\mathrm{pH}$ 6.46) and detected by UV absorption at $254 \mathrm{~nm}$. The chromatograms were analysed using the Waters Millennium software package 
(Waters Corp.). Homocysteine concentrations in samples of maternal serum were measured as described previously (Petrie et al. 2002).

\section{Folate analysis}

Folic acid was estimated using the SimulTRAC* Radioassay Kit (Cat 06B262226; MP Biomedicals, Basingstoke, Hampshire, UK). If necessary, plasma samples were diluted 1:1 with Standard A. Liver samples were homogenised in 10 volumes of $0.02 \mathrm{M}-\mathrm{Na}_{2} \mathrm{PO}_{4}$ buffer $(\mathrm{pH} 7.5)$, and a portion was used to estimate the protein content. A second portion was diluted fifty times with $0.02 \mathrm{M}$-sodium borate buffer $(\mathrm{pH} 7.5)$ and used for the folate assay, which was performed according to the manufacturer's instructions. Concentrations in the samples were determined using a standard curve. Tissue samples were further diluted where necessary to ensure that unknowns were on the linear portion of the standard curve.

\section{Choline analysis}

Approximately $0 \cdot 2 \mathrm{~g}$ tissue was homogenised in $1 \mathrm{ml}$ ice-cold $0 \cdot 145 \mathrm{M}-\mathrm{NaCl}$. An aliquot was removed to estimate the protein content, and the remaining homogenate was extracted with $10 \mathrm{ml}$ chloroform:methanol $(2: 1 \mathrm{v} / \mathrm{v})$. After $30 \mathrm{~min}$ on a rotary mixer, $3 \mathrm{ml}$ distilled water were added and briefly mixed before centrifugation at $1600 \mathrm{~g} 10 \mathrm{~min}$. The supernatant was removed and the residue further extracted with $3 \mathrm{ml}$ chloroform:methanol $0 \cdot 145 \mathrm{M}-\mathrm{NaCl}(3: 48: 47 \mathrm{v} / \mathrm{v})$. The combined supernatants were lyophilised, reconstituted in $1 \mathrm{ml} 50 \mathrm{~mm}-$ tris/ $\mathrm{HCl}(\mathrm{pH} 7 \cdot 8)$ and decolourised with approximately $30 \mathrm{mg}$ activated charcoal.

Choline and phosphocholine in the extract was treated with choline oxidase (EC 1.1.3.17), and the $\mathrm{H}_{2} \mathrm{O}_{2}$ formed in the reaction was detected with a chromogenic reagent containing 4-aminoantipyrine (Blaton et al. 1983). Briefly, six $100 \mu \mathrm{l}$ volumes of each sample were transferred to a 96-well reaction plate. The first two aliquots were used as a reagent blank by adding $30 \mu \mathrm{l}$ chromogenic reagent. The choline content of the second two aliquots was determined by adding $30 \mu \mathrm{l}$ chromogenic reagent containing $2 \mathrm{U}$ choline oxidase (Sigma, Poole, Dorset, UK) per ml. The total choline plus phosphocholine content was determined by incubating the remaining two aliquots at $37^{\circ} \mathrm{C}$ for $30 \mathrm{~min}$ with $0.3 \mathrm{U}$ alkaline phosphatase (Roche Diagnostics, Lewes, Sussex, UK) in $50 \mathrm{~mm}$-tris/ $\mathrm{HCl}$ buffer ( $\mathrm{pH} 8.0)$ before the addition of $30 \mu$ l chromogenic reagent containing choline oxidase. The plate was incubated at $37^{\circ} \mathrm{C}$ for $90 \mathrm{~min}$ for colour development before the absorbance at $500 \mathrm{~nm}$ was read on a microplate reader. The values were corrected for the reagent blank and choline concentrations determined from a standard curve. The choline and phosphocholine concentrations in the samples were determined by difference.

\section{DNA methylation}

Global DNA methylation was measured using the cytosine extension assay (Pogribny et al. 1999). Samples of frozen tissue were powdered under liquid N, and DNA was extracted using the GeneElute kit (Sigma) following the manufacturer's instructions. The DNA samples were incubated overnight at $37^{\circ} \mathrm{C}$ to ensure that they were completely rehydrated before being stored as a $50 \mathrm{ng} / \mu \mathrm{l}$ solution at $4^{\circ} \mathrm{C}$. The sex of the fetal DNA samples was determined by PCR amplification of the Sry gene, as previously described (Maloney et al. 2005).

For the cytosine extension assay, aliquots of $250 \mathrm{ng}$ DNA were transferred to 96-well plates and digested overnight at $37^{\circ} \mathrm{C}$ with $10 \mathrm{U}$ either HpaII or MspI per $\mu \mathrm{g}$ DNA (New England Biolabs, Hitchin, Hertfordshire, UK) using the buffers supplied with the enzymes. The enzyme digests were then end-filled by incubating for $1 \mathrm{~h}$ at $56^{\circ} \mathrm{C}$ with $2.8 \mathrm{kBq}\left[{ }^{3} \mathrm{H}\right] \mathrm{dCTP}(1.6 \mathrm{TBq} /$ mmol; PerkinElmer, Beaconsfield, Buckinghamshire, UK) and 0.25 U Taq DNA polymerase (Promega, Southampton, Hampshire, UK) using the buffer supplied by the manufacturer. The reaction was cooled on ice, and the mix was then applied to DE51 paper (Whatman, Maidstone, Kent, UK) supported in a 96-well format dot blot apparatus. Each well was washed six times with $0.2 \mathrm{ml} 0.5 \mathrm{M}-\mathrm{Na}_{2} \mathrm{PO}_{4}$ buffer ( $\mathrm{pH} 7 \cdot 0$ ). The filter was removed, given two additional washes in phosphate buffer, briefly rinsed in water, washed with $70 \%$ ethanol and allowed to air-dry. The filter was cut into sections, which were transferred to scintillation vials. The radioactivity in each sample was then determined by liquid scintillation-counting using $5 \mathrm{ml}$ Ultima Gold scintilant (Perkin Elmer). The percentage of cytosine residues that were not methylated (\% unmethylated) was calculated from the relative incorporation of radioactivity (Pogribny et al. 1999).

\section{Statistics}

All data are presented as mean values and their standard errors. Data were analysed by one-way ANOVA followed by Fisher's multiple comparison test (Genstat 7 statistical package; Lawes Agricultural Trust, Rothamsted Experimental Station, Harpenden, Hertfordshire, UK). The block structure of the data took the dam into account in the analysis of fetal weights.

\section{Results}

\section{Maternal growth}

The growth of the animals is summarised in Table 2. The weight gain of animals fed the $-\mathrm{F}$ diet or the $-\mathrm{F}$ LC diet during the pre-mating period and during gestation was no different from that of the animals in the control group. The animals fed the $-\mathrm{F}$ LM and $-\mathrm{F}$ LM LC diets gained less weight during the pre-mating period and during gestation when compared with animals in the control group. The number of fetuses was not affected by the folate, choline or methionine content of the diets. Fetuses of dams fed the $-\mathrm{F}$ diet were approximately $17 \%$ heavier than the controls, whereas those from dams fed the two low-methionine diets (-F LM, -F LM LC) were 9-14\% smaller than the controls.

\section{Folate concentrations in maternal and fetal livers}

Figure 2 shows that, by day 21 of gestation, serum folate concentrations of the dams fed the $-\mathrm{F}$ diet were only $31 \%$ of 
control values. Serum folate concentrations were higher in the animals fed the $-F$ LM diet compared with the $-F$ diet, although they were still lower than those of controls. The folate-deficient diets reduced the folate content of the maternal liver to approximately $20 \%$ of values found in animals fed the control diet. The concentrations of folic acid in the fetal liver were also reduced by folic acid deficiency in the maternal diet by $70 \%$ compared with the controls. The methionine or choline content of the maternal diet did not lead to additional changes in folate concentration in the fetal liver.

\section{Choline and phosphocholine concentrations in the maternal liver}

Folate deficiency increased free choline concentrations by approximately 2-fold with a corresponding decrease in phosphocholine concentrations (Fig. 3). The - F LM diet also reduced the phosphocholine concentrations to a similar extent as the $-\mathrm{F}$ diet. There was an intermediate effect on choline concentrations in the liver of animals fed the - F LM diet. There was a further decline in the phosphocholine levels to approximately $25 \%$ of those found in the controls when the folate-deficient diet was also low in choline ( $-\mathrm{F}$ LC, $-\mathrm{F}$ LM LC). The free choline concentration was unaffected by a low dietary choline content and was similar to that of animals fed the control diet.

\section{Free amino acid pools}

Feeding a folate-deficient diet increased homocysteine concentrations by $4 \cdot 5$-fold and by $6-7$-fold in the dams fed -F LC diets (Fig. 4). There were also significant changes in the serum amino acid profiles of both dam (Table 3) and fetus (Table 4). A folate-deficient diet increased the concentrations of glycine in the maternal serum, and this was elevated further when the methionine content of the maternal diet was low (i.e. the - F LM and - F LM LC diets). Folate deficiency alone did not affect glycine concentrations in the fetal serum, but these were increased when folate deficiency was combined with low methionine levels in the maternal diet. Glycine concentrations were increased by 1.7 -fold in the fetus compared with a 2.6-fold increase in the maternal circulation. Serine and threonine concentrations also increased in both the dam and fetal serum by $1 \cdot 5-2$-fold in the animals fed the - F LM and - F LM LC diets. Reducing the methionine content of the diet reduced cystine concentrations by approximately $20 \%$ in the maternal serum. Taurine concentrations were reduced by approximately $15 \%$ in the fetal but not the maternal serum of animals fed the low-methionine ( $-\mathrm{F}$ LM, -F LM LC) diets. There were also small changes in tyrosine and tryptophan concentrations.

\section{DNA methylation}

The global methylation of DNA in the maternal and fetal livers was assessed using the cytosine extension assay (Table 5). The number of methyl cytosine residues in the restriction enzyme recognition sequence was unchanged in the livers of dams fed the $-\mathrm{F}$ or $-\mathrm{F}$ LM LC diet when compared with the control diet. The overall level of cytosine methylation was lower in fetal than maternal liver. The gender of 

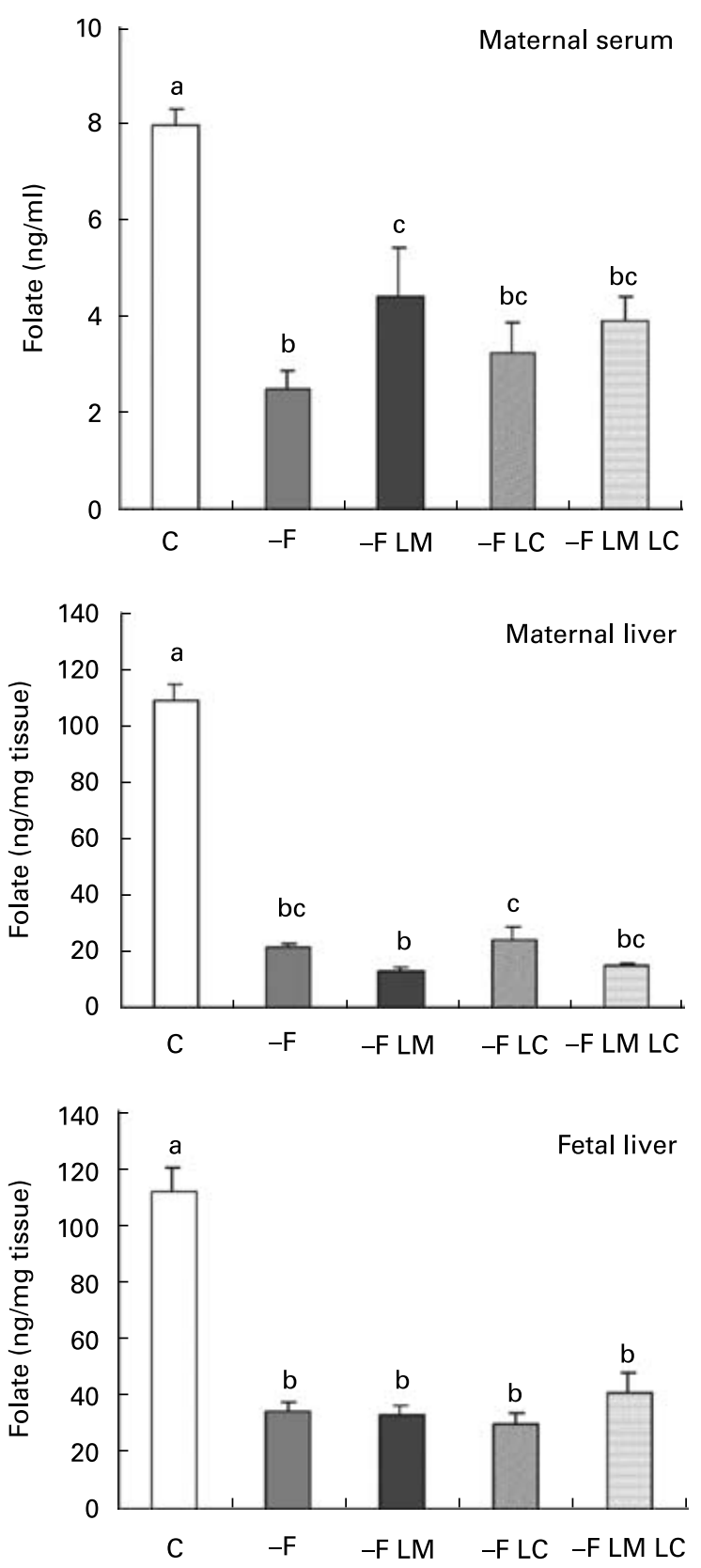

Fig. 2. Folate concentrations (mean values and their standard errors) in maternal serum (control $n 8,-\mathrm{F} n 6,-\mathrm{F}$ LM $n 5,-\mathrm{F}$ LC $n 6$, - F LM LC $n$ 6), maternal liver (control $n 6,-\mathrm{F} n 6,-\mathrm{F}$ LM $n 5$, $-\mathrm{F}$ LC $n 6,-\mathrm{F}$ LM LC $n$ 6) and fetal liver (control $n 6,-\mathrm{F} n 6,-\mathrm{F} \mathrm{LM} n 5,-\mathrm{F} \mathrm{LC} n 6,-\mathrm{F}$ LM LC $n$ 6). Data were analysed post hoc by Fischer's unprotected test. ${ }^{\mathrm{a}, \mathrm{b}, \mathrm{c}}$ Mean values with unlike letters were significantly different $(P<0.05)$.

the fetus did not change the degree of cytosine methylation (sex $P=0.194$, diet $P=0.079$, diet $\times$ sex $P=0.131$ ).

\section{Discussion}

Recent studies that have implicated the methionine cycle and methyl group metabolism in the longer-term programming of hypertension and metabolism have utilised supplementation to achieve their effects (Brawley et al. 2004; Lillycrop et al. 2005). This is thought to be the first study to quantify the effects of diets deficient in folic acid, choline and methionine

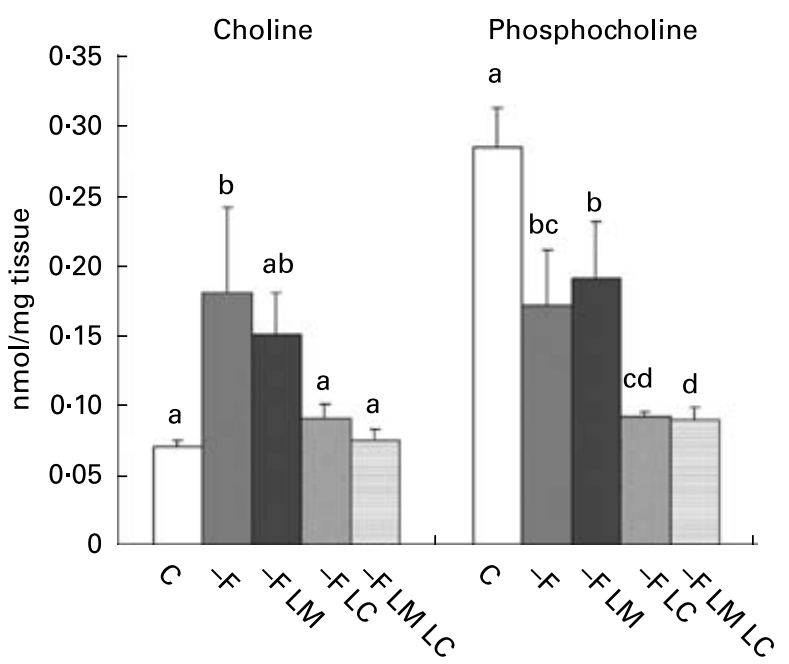

Fig. 3. Concentrations (mean values and their standard errors) of choline and phosphocholine in maternal liver (control $n 8,-\mathrm{F} n 6,-\mathrm{F} \mathrm{LM} n 5,-\mathrm{F}$ LC $n 6,-\mathrm{F}$ LM LC $n$ 7). Data were analysed post hoc by Fischer's unprotected test. ${ }^{a, b, c, d}$ Mean values with unlike letters were significantly different $(P<0.05)$.

on the amino acid supply in the pregnant animal and also to show changes in choline metabolism resulting from folate deficiencies within the range observed in human populations.

The diet is not the only source of folic acid; the rat is also able to utilise folate produced by intestinal micro-organisms (Rong et al. 1991). The available evidence suggests, however, that this source makes a relatively small contribution to hepatic stores (Sepehr et al. 2003). This is clearly the case for the pregnant rat, for which removing folic acid from the diet increases maternal plasma homocysteine concentrations by approximately 5-fold, indicating that these animals are functionally folate deficient. Furthermore, the range of homocysteine concentration in this study is similar to that observed in normal human subjects who are not receiving folate supplements (4.30-22.35 $\mu \mathrm{mol} / \mathrm{l}$; Murphy et al. 2004).

In addition to homocysteine, a restriction in the methyl supply also alters the concentrations of a number of amino

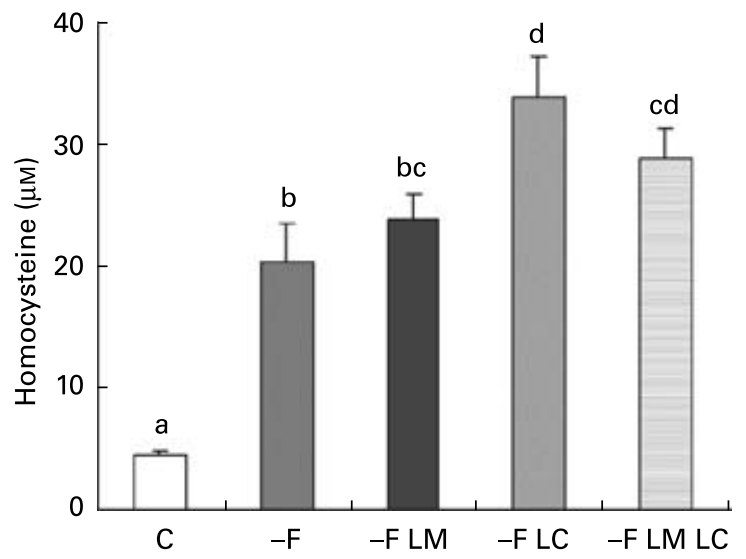

Fig. 4. Homocysteine concentrations (mean values and their standard errors) in maternal serum (control $n 5,-\mathrm{F} n 4,-\mathrm{F}$ LM $n 5,-\mathrm{F} \mathrm{LC} n 5,-\mathrm{F}$ LM LC $n 5)$. Data were analysed post hoc by Fischer's unprotected test. ${ }^{\text {a,b,c,d }}$ Mean values with unlike letters were significantly different $(P<0.05)$. 
Table 3. Free amino acid concentrations in maternal serum

(Mean values with their standard errors)

\begin{tabular}{|c|c|c|c|c|c|c|c|c|c|c|c|}
\hline \multirow[t]{2}{*}{ Diet ... } & \multicolumn{2}{|c|}{ Control (n 8) } & \multicolumn{2}{|c|}{$-\mathrm{F}(n 6)$} & \multicolumn{2}{|c|}{$-\mathrm{F} \mathrm{LM}(n 5)$} & \multicolumn{2}{|c|}{$-\mathrm{F} \mathrm{LC}(n 6)$} & \multicolumn{2}{|c|}{$-\mathrm{F}$ LM LC $(n 7)$} & \multirow[b]{2}{*}{$P$} \\
\hline & Mean & SE & Mean & $\mathrm{SE}$ & Mean & SE & Mean & SE & Mean & $\mathrm{SE}$ & \\
\hline Asp & 7 & 1 & 8 & 1 & 9 & 1 & 9 & 2 & 7 & 0 & NS \\
\hline Glu & 139 & 7 & 115 & 11 & 146 & 12 & 109 & 9 & 134 & 11 & NS \\
\hline Ser & 276 & $8^{\mathrm{a}}$ & 357 & $14^{\mathrm{ab}}$ & 485 & $78^{\mathrm{b}}$ & 374 & $24^{\mathrm{a}}$ & 531 & $39^{\mathrm{b}}$ & $<0.001$ \\
\hline Asn & 78 & 5 & 89 & 3 & 86 & 6 & 83 & 4 & 85 & 4 & NS \\
\hline Gly & 137 & $11^{\mathrm{a}}$ & 239 & $29^{b}$ & 355 & $34^{\mathrm{c}}$ & 208 & $24^{\mathrm{b}}$ & 355 & $27^{c}$ & $<0.001$ \\
\hline Gln & 721 & 22 & 697 & 26 & 631 & 68 & 682 & 36 & 608 & 29 & NS \\
\hline Tau & 153 & 35 & 184 & 36 & 149 & 8 & 143 & 14 & 130 & 8 & NS \\
\hline His & 20 & 2 & 22 & 2 & 24 & 3 & 26 & 5 & 24 & 2 & NS \\
\hline Thr & 178 & $9^{a}$ & 206 & $19^{\mathrm{ab}}$ & 288 & $52^{b c}$ & 254 & $30^{\mathrm{ab}}$ & 364 & $36^{c}$ & $<0.001$ \\
\hline Ala & 556 & 51 & 452 & 34 & 505 & 90 & 475 & 53 & 435 & 23 & NS \\
\hline Arg & 74 & 5 & 68 & 3 & 75 & 6 & 71 & 7 & 76 & 3 & NS \\
\hline Pro & 239 & 23 & 205 & 11 & 234 & 35 & 196 & 13 & 223 & 14 & NS \\
\hline Tyr & 51 & $4^{\mathrm{a}}$ & 73 & $9^{b}$ & 47 & $4^{a}$ & 57 & $7^{a}$ & 45 & $2^{\mathrm{ab}}$ & 0.011 \\
\hline Val & 103 & 4 & 120 & 7 & 105 & 7 & 125 & 10 & 116 & 6 & NS \\
\hline Met & 47 & 2 & 43 & 2 & 44 & 3 & 42 & 3 & 45 & 1 & NS \\
\hline Ile & 58 & 4 & 69 & 6 & 62 & 4 & 68 & 4 & 67 & 3 & NS \\
\hline Leu & 75 & 5 & 88 & 6 & 80 & 4 & 89 & 6 & 88 & 5 & NS \\
\hline Phe & 53 & 3 & 53 & 3 & 57 & 3 & 54 & 4 & 57 & 3 & NS \\
\hline Trp & 46 & $2^{a b}$ & 46 & $3^{a b c}$ & 40 & $2^{c}$ & 51 & $2^{b}$ & 44 & $2^{\mathrm{ac}}$ & 0.021 \\
\hline Lys & 859 & 48 & 964 & 61 & 965 & 81 & 921 & 75 & 932 & 39 & NS \\
\hline Cys* & 130 & $3^{a}$ & 125 & $6^{a}$ & 103 & $10^{\mathrm{b}}$ & 120 & $6^{a}$ & 103 & $7^{\mathrm{b}}$ & 0.029 \\
\hline
\end{tabular}

Data were analysed post hoc by Fisher's unprotected test.

- F, folate deficient; - F LM, folate deficient with low methionine; -F LC, folate deficient with low choline; - F LM LC, folate deficient, low methionine, low choline determination.

a,b,c Mean values within a row with unlike superscript letters were significantly different $(P<0.05)$. NS, not significant.

${ }^{*}$ Cystine concentrations determined in a separate sample as part of the homocysteine.

acids, particularly glycine, serine and threonine, in both the maternal and fetal plasma. Both glycine (Jackson et al. 2002) and threonine (Rees et al. 1999) have also been implicated in the programming of fetal development by maternal protein deficiency. This study shows that diets deficient in methyl donors increase the plasma concentrations of all three amino acids, in contrast to the low-protein diet, which does not change glycine and serine and reduces threonine concentrations (Rees et al. 1999). Another important difference is that concentrations of the branched chain amino acids are unchanged by folate deficiency, whereas concentrations fall when animals are fed low-protein diets. These altered profiles suggest that the animals receiving folate-deficient diets have a very different metabolic state compared with those fed lowprotein diets.

Although the amino acid profile of fetal plasma mirrors the changes in the maternal circulation, the differences are less pronounced, suggesting that a restricted supply of methyl donors affects dam and fetus differently. The data suggest that there are major changes in glycine, serine and threonine metabolism in the dam and that the fetus is affected to a lesser extent. The folate concentration in the fetal liver is nearly $50 \%$ higher than that in the maternal liver, suggesting that the limited folate available in the maternal serum is preferentially distributed to the fetus. This additional folate may be sufficient to support more appropriate metabolic activity in the fetal compartment. These results show that the positive relationship between glycine supply and folate availability that is inferred to occur following an increase in folate intake (Torrens et al. 2006) cannot be extended into the deficient state. The increased glycine concentrations found in deficient animals suggest that the glycine supply is improved in animals with a poor folate status.

Placental serine hydroxymethyltransferase (SHMT; reaction (a) in Fig. 1) is one of three folate-dependent enzymes that metabolises glycine (Dickson et al. 2005). In the absence of 5-methyl tetrahydrofolate, SHMT can cleave threonine to aldehydes and glycine (Webb \& Matthews, 1995). Changes in SHMT activity would be expected to produce reciprocal changes in glycine and serine or glycine and threonine, whereas the data show that the concentrations of threonine, serine and glycine are all increased by folate deficiency. Although this observation does not rule out a role for SHMT, it does suggest that the response to a change in the diet is more complex.

The highest plasma concentrations of glycine and serine were found in the animals fed the diets with the lower methionine content (the LM diet groups), suggesting a role for methionine metabolism. The conversion of one molecule of methionine to cysteine for utilisation or oxidation requires one molecule of glycine and one of serine (reactions (b) and (c) in Fig. 1). Even in the control diets, a significant amount of methionine must be converted to cysteine in order to redress the imbalance in the sulphur amino acid composition of the diet (Rees, 2002). The relationship between folate status, methionine intake and glycine supply is, however, complex because of the kinetics of glycine- $N$ methyl transferase (reaction (b) in Fig. 1). The activity of this enzyme is regulated at the transcriptional level by the availability of methionine (Rowling et al. 2002) and also by 5-methyl-tetrahydrofolate, which is an allosteric inhibitor (Wagner et al. 1985). The relative importance of SHMT 
Table 4. Free amino acid concentrations in fetal serum

(Mean values with their standard errors)

\begin{tabular}{|c|c|c|c|c|c|c|c|c|c|c|c|}
\hline \multirow[t]{2}{*}{ Diet . } & \multicolumn{2}{|c|}{ Control ( $n$ 8) } & \multicolumn{2}{|c|}{$-\mathrm{F}(n 6)$} & \multicolumn{2}{|c|}{$-\mathrm{F} \mathrm{LM}(n 5)$} & \multicolumn{2}{|c|}{$-\mathrm{F} \mathrm{LC}(n 6)$} & \multicolumn{2}{|c|}{$-\mathrm{F} \mathrm{LM} \mathrm{LC}(n 7)$} & \multirow[b]{2}{*}{$P$} \\
\hline & Mean & SE & Mean & SE & Mean & SE & Mean & SE & Mean & SE & \\
\hline Asp & 32 & $2^{a}$ & 26 & $2^{a b}$ & 21 & $2^{\mathrm{b}}$ & 31 & $2^{a}$ & 22 & $2^{b}$ & 0.002 \\
\hline Glu & 309 & 10 & 267 & 21 & 272 & 12 & 297 & 14 & 292 & 15 & NS \\
\hline Ser & 474 & $20^{a}$ & 650 & $51^{b}$ & 923 & $82^{c}$ & 713 & $38^{\mathrm{b}}$ & 887 & $52^{c}$ & $<0.001$ \\
\hline Asn & 192 & 11 & 185 & 13 & 237 & 33 & 204 & 11 & 213 & 12 & NS \\
\hline Gly & 449 & $26^{a}$ & 385 & $18^{\mathrm{a}}$ & 723 & $80^{\mathrm{b}}$ & 374 & $18^{a}$ & 789 & $23^{\mathrm{b}}$ & $<0.001$ \\
\hline Gln & 1400 & 28 & 1354 & 119 & 1302 & 155 & 1439 & 34 & 1261 & 90 & NS \\
\hline Tau & 504 & $10^{\mathrm{a}}$ & 482 & $28^{a b}$ & 412 & $20^{\mathrm{b}}$ & 513 & $33^{\mathrm{a}}$ & 423 & $25^{\mathrm{b}}$ & 0.015 \\
\hline $\mathrm{His}$ & 33 & 6 & 28 & 4 & 22 & 6 & 53 & 26 & 22 & 2 & NS \\
\hline Thr & 486 & $23^{a}$ & 474 & $60^{\mathrm{a}}$ & 724 & $87^{\mathrm{bc}}$ & 615 & $58^{\mathrm{ab}}$ & 806 & $67^{c}$ & $<0.001$ \\
\hline Ala & 1284 & 49 & 1217 & 91 & 1360 & 237 & 1243 & 65 & 1145 & 77 & NS \\
\hline Arg & 130 & 8 & 133 & 8 & 123 & 21 & 149 & 13 & 131 & 10 & NS \\
\hline Pro & 393 & 14 & 347 & 37 & 442 & 67 & 382 & 32 & 384 & 27 & NS \\
\hline Tyr & 322 & $13^{a}$ & 357 & $27^{a}$ & 260 & $23^{\mathrm{bc}}$ & 320 & $23^{\mathrm{ab}}$ & 234 & $11^{\mathrm{c}}$ & $<0.001$ \\
\hline Val & 451 & 17 & 417 & 33 & 411 & 57 & 467 & 39 & 385 & 19 & NS \\
\hline Met & 151 & 4 & 124 & 7 & 138 & 15 & 142 & 8 & 134 & 7 & NS \\
\hline Ile & 148 & 9 & 154 & 8 & 150 & 21 & 161 & 11 & 145 & 8 & NS \\
\hline Leu & 301 & 14 & 293 & 20 & 299 & 42 & 325 & 25 & 289 & 15 & NS \\
\hline Phe & 287 & 14 & 215 & 19 & 285 & 37 & 265 & 22 & 249 & 17 & NS \\
\hline Trp & 116 & $5^{\mathrm{ab}}$ & 115 & $9^{\mathrm{ab}}$ & 99 & $8^{a}$ & 124 & $3^{b}$ & 102 & $5^{a}$ & 0.05 \\
\hline Lys & 1995 & 92 & 2168 & 81 & 2290 & 285 & 2151 & 102 & 1964 & 111 & NS \\
\hline
\end{tabular}

Data were analysed post hoc by Fisher's unprotected test.

$-\mathrm{F}$, folate deficient; - F LM, folate deficient with low methionine; - F LC, folate deficient with low choline; - F LM LC, folate deficient, low methionine, low choline.

${ }^{a, b, c}$ Mean values within a row with unlike superscript letters were significantly different $(P<0.05)$. NS, not significant.

and glycine- $N$-methyl transferase cannot be established from the present data, but this is clearly an area worthy of further investigation.

Although animals fed the LM diets had only half the methionine intake of the controls, plasma methionine concentrations were unchanged; suggesting that free methionine in the plasma is tightly regulated even when the methyl supply is restricted. The reduced growth of animals in the LM diet groups presumably lowers demand and makes additional methionine available for biosynthesis. The methionine content of the diet also affected taurine concentrations in the fetus. Taurine is required by the developing islets and is implicated in the adverse effects of protein deficiency (Cherif et al. 1998). Diets high in methionine increase fetal taurine concentrations, suggesting that the methionine content of the maternal diet is an important influence on fetal development.
As hepatic folic acid concentrations declined in animals fed the folate-deficient diet, free choline concentrations increased. This was at the expense of hepatic phosphocholine, the major storage form of choline and occurred even when the diet contained sufficient choline. The additional choline mobilised from the reserves was probably not used as a methyl donor as maternal diets low in methionine did not further deplete hepatic phosphocholine or lead to an additional increase in plasma homocysteine concentration. It is more likely that the hepatic phosphocholine stores provide choline previously produced by folate-dependent reactions. Reducing the choline content of the diet ( $-\mathrm{F}$ LC) caused an additional decrease in hepatic phosphocholine consistent with an increase in the use of reserves to meet a shortfall in the diet. In addition, there was no evidence for an additive effect of methionine and choline deficiency, which might be expected were both being used

Table 5. DNA methylation

(Mean values with their standard errors)

\begin{tabular}{|c|c|c|c|c|c|c|c|}
\hline Diet ... & \multicolumn{2}{|c|}{ Control } & \multicolumn{2}{|c|}{$-F$} & \multicolumn{2}{|c|}{$-F$ LM LC } & \multirow[b]{3}{*}{$P$} \\
\hline Number of dams & \multicolumn{2}{|c|}{5} & \multicolumn{2}{|c|}{5} & \multicolumn{2}{|c|}{5} & \\
\hline Unmethylated cytosine & Mean & SE & Mean & SE & Mean & SE & \\
\hline \multicolumn{8}{|l|}{ Residues (\% total) } \\
\hline Maternal liver & $25 \cdot 6$ & 1.56 & $24 \cdot 7$ & 0.515 & $27 \cdot 7$ & 1.45 & 0.253 \\
\hline Fetal liver* & $34 \cdot 2$ & $1.80^{\mathrm{ab}}$ & $30 \cdot 0$ & $2 \cdot 84^{a}$ & $37 \cdot 7$ & $2 \cdot 49^{b}$ & 0.060 \\
\hline$n$ & \multicolumn{2}{|c|}{12} & \multicolumn{2}{|c|}{9} & \multicolumn{2}{|c|}{11} & \\
\hline
\end{tabular}

Data were analysed by one-way ANOVA taking the dam into account in the block structure.

- F, folate deficient; - F LM, folate deficient with low methionine; - F LC, folate deficient with low choline; - F LM LC, folate deficient, low methionine, low choline.

${ }^{a, b}$ Mean values within a row with unlike superscript letters were significantly different $(P<0.05)$

* Where possible the DNA from at least one male and one female fetus from each litter was analysed. 
as methyl donors. In male rats, folate deficiency reduced free choline concentrations in the liver but had no effect on phosphocholine concentrations (Kim et al. 1994). This suggests that folate deficiency in the pregnant female can increase the demand for total choline, exacerbating the depletion of phosphocholine stores that normally occurs during pregnancy (Zeisel et al. 1995). The adverse effects of this extra demand are unknown but may be important in situations where both folate and choline supply is marginal.

Methyl groups derived from $S$-adenosyl methionine are essential co-factors for the methyltransferases that modify DNA and chromatin. It is possible to envisage situations in which the availability of S-adenosyl methionine (or inhibition by S-adenosyl homocysteine) alters methyltransferase expression, the steady-state reaction of the enzyme or the procession of the enzyme along the DNA. A change in any or all of these factors could modify cytosine methylation at sites where the methyltransferases were active.

The cytosine extension assay is limited to the sequences cut by the HpaII and MspI restriction enzymes. As these are more frequently found in $\mathrm{CpG}$ islands compared with other sites in the genome, this may bias the result of the assay. In particular, the possibility remains that folate deficiency can lead to more specific changes in the methylation status of localised sites. A change in the kinetics of methyl transfer cannot, however, distinguish between specific sites in the genome, with cytosine residues in the MspI/HpaII recognition site being representative of those modified by methyltransferase activity. Hypermethylation of DNA may be a consequence of an unbalanced diets containing a high proportion of methionine relative to other amino acids (Rees et al. 2000).

In contrast, the present study has used diets low in methionine to create a deficiency in methyl donors. Under these conditions, there is no change in the methylation of DNA in the MspI/HpaII recognition sites within the maternal liver DNA, and at best the data suggest a weak trend $(P=0 \cdot 06)$ towards hypomethylation of DNA in the fetal liver. Methylation, however, tended to be increased in the folate-deficient $(-F)$ group and decreased by the combined deficiency ( - F LM LC). This is only partly consistent with the hypothesis that there is a progressive reduction in DNA methylation as methyl donors are removed from the diet. Furthermore, global DNA methylation was not correlated with either hepatic folate or plasma homocysteine concentrations, showing that an increase of approximately 5-fold in maternal plasma homocysteine has no impact on DNA methylation in maternal or fetal liver.

Previous studies have shown that prolonged chronic dietary insufficiency (diets devoid of folate and choline) increased the number of unmethylated cytosine residues in the available restriction sites in the liver from approximately $22 \%$ in the control to approximately $54 \%$ after 36 weeks of feeding (Pogribny et al. 2004). Other studies in which animals were subjected to a more modest restriction of the folate supply are more in keeping with the present results, failing to show a change in the global methylation of DNA (Kim et al. 1995). It is, however, important to note that the fetal liver develops behind the placental barrier. Critical methylation reactions also take place during the early stages of development. The developing oocyte and pre-implantation embryo are more exposed to the maternal circulation and may therefore be more vulnerable.
This study shows that diets deficient in methyl donors do not directly influence the methylation of DNA, and suggests a secondary mechanism. It is clear from the increases in plasma homocysteine, glycine, serine and threonine that there are major changes in the underlying methyl metabolism in animals fed these deficient diets. It is more likely that these changes in metabolism exert indirect effects on the genome. Specific metabolites may interact with transcriptional activators and modify the process of differential methylation of DNA that occurs during development. Where this influences critical regulatory genes such as $\operatorname{PPAR} \alpha$ (Lillycrop et al. 2005), it can lead to long-term modification of gene expression. Phosphatidyl choline synthesis via phosphatidyl ethanolamine methyltransferase is quantitatively a much larger consumer of methyl groups compared with DNA methylation (Stead et al. 2006). Widespread changes in lipid metabolism (Hay et al. 2005) resulting from a reduced flux through the methionine cycle may be a potential indirect mechanism leading to specific changes in the methylation of regulatory genes such as PPAR $\alpha$.

\section{Acknowledgements}

This work was supported by the Scottish Executive, Environment and Rural Affairs Department as part of the Rowett Research Institute core funding. Dr C. A. Maloney is supported by a cooperative agreement from the National Institutes of Health (U01 HD044638) as a component of the NICHD Cooperative Program on Female Health and Egg Quality. We thank Dr G. Lobley and Dr F. Wilson for valuable discussions. We also express our thanks to staff from Bioresources Unit for animal care, to V. Buchan, to S. Duthie for amino acid analysis and to Dr G. Holtrop (Biomathematics and Statistics, Scotland) for advice on the statistical analysis.

\section{References}

Blaton V, De Buyzere M, Spincemaille J \& Declercq B (1983) Enzymic assay for phosphatidylcholine and sphingomyelin in serum. Clin Chem 29, 806-809.

Brawley L, Torrens C, Anthony FW, Itoh S, Wheeler T, Jackson AA, Clough GF, Poston L \& Hanson MA (2004) Glycine rectifies vascular dysfunction induced by dietary protein imbalance during pregnancy. J Physiol (Lond) 554, 497-504.

Bieri JG, Stoewsand GS, Briggs GM, Phillip RW, Woodard JC \& Knapka JJ (1977) Report of the American Institute of Nutrition Ad Hoc committee on standards for nutritional studies. J Nutr 107, 1340-1348.

Caudill MA, Wang JC, Melnyk S, Pogribny IP, Jernigan S, Collins MD, Santos-Guzman J, Swendseid ME, Cogger EA \& James SJ (2001) Intracellular S-adenosylhomocysteine concentrations predict global DNA hypomethylation in tissues of methyl-deficient cystathionine beta-synthase heterozygous mice. $J$ Nutr 131, 2811-2818.

Cherif H, Reusens B, Ahn MT, Hoet JJ \& Remacle C (1998) Effects of taurine on the insulin secretion of rat fetal islets from dams fed a low-protein diet. J Endocrinol 159, 341-348.

Choumenkovitch SF, Selhub J, Bagley PJ, Maeda N, Nadeau MR, Smith DE \& Choi SW (2002) In the cystathionine $\beta$-synthase knockout mouse, elevations in total plasma homocysteine increase tissue S-adenosylhomocysteine, but responses of S-adenosylmethionine and DNA methylation are tissue specific. J Nutr 132, 2157-2160. 
Dickson TM, Edison E, Brosnan JT \& House JD (2005) Hyperglycinemia due to folate deficiency in rats: evidence for the lack of involvement of the hepatic glycine cleavage system. J Nutr Biochem 16, 736-742.

Hay SM, Maloney CA \& Rees WD (2005) Dietary folate, methionine and choline deficiency increases plasma homocysteine and modifies lipid metabolism in the dam, changing insulin in the rat fetus. Pediatr Res 58, 1114.

Hoffman DR, Marion DW, Cornatzer WE \& Duerre JA (1980) S-Adenosylmethionine and S-adenosylhomocystein metabolism in isolated rat liver. Effects of L-methionine, L-homocystein, and adenosine. J Biol Chem 255, 10822-10827.

Jackson AA, Dunn RL, Marchand MC \& Langley-Evans SC (2002) Increased systolic blood pressure in rats induced by a maternal low-protein diet is reversed by dietary supplementation with glycine. Clin Sci (Lond) 103, 633-639.

James SJ, Melnyk S, Pogribna M, Pogribny IP \& Caudill MA (2002) Elevation in S-adenosylhomocysteine and DNA hypomethylation: potential epigenetic mechanism for homocysteine-related pathology. J Nutr 132, 2361S-2366S.

Kim YI, Christman JK, Fleet JC, Cravo ML, Salomon RN, Smith D, Ordovas J, Selhub J \& Mason JB (1995) Moderate folate deficiency does not cause global hypomethylation of hepatic and colonic DNA or c-myc-specific hypomethylation of colonic DNA in rats. Am J Clin Nutr 61, 1083-1090.

Kim YI, Miller JW, da Costa KA, Nadeau M, Smith D, Selhub J, Zeisel SH \& Mason JB (1994) Severe folate deficiency causes secondary depletion of choline and phosphocholine in rat liver. $J$ Nutr 124, 2197-2203.

Langley-Evans SC, Gardner DS \& Jackson AA (1996) Association of disproportionate growth of fetal rats in late gestation with raised systolic blood pressure in later life. J Reprod Fertil 106, 307-312.

Lillycrop KA, Phillips ES, Jackson AA, Hanson MA \& Burdge GC (2005) Dietary protein restriction of pregnant rats induces and folic acid supplementation prevents epigenetic modification of hepatic gene expression in the offspring. J Nutr 135, 1382-1386.

MacLennan NK, James SJ, Melnyk S, Piroozi A, Jernigan S, Hsu JL, Janke SM, Pham TD \& Lane RH (2004) Uteroplacental insufficiency alters DNA methylation, one-carbon metabolism, and histone acetylation in IUGR rats. Physiol Genomics 18, 43-50.

Maloney CA, Lilley C, Cruickshank M, McKinnon C, Hay SM \& Rees WD (2005) The expression of growth-arrest genes in the liver and kidney of the protein-restricted rat fetus. Br J Nutr 94, 12-18.

Murphy MM, Scott JM, Arija V, Molloy AM \& Fernandez-Ballart JD (2004) Maternal homocysteine before conception and throughout pregnancy predicts fetal homocysteine and birth weight. Clin Chem 50, 1406-1412.

Petrie L, Duthie SJ, Rees WD \& McConnell JM (2002) Serum concentrations of homocysteine are elevated during early pregnancy in rodent models of fetal programming. Br J Nutr 88, 471-477.

Pogribny IP, James SJ, Jernigan S \& Pogribna M (2004) Genomic hypomethylation is specific for preneoplastic liver in folate/ methyl deficient rats and does not occur in non-target tissues. Mutat Res Fundam Mol Mech Mutagen 548, 53-59.

Pogribny I, Yi P \& James SJ (1999) A sensitive new method for rapid detection of abnormal methylation patterns in global DNA and within CpG islands. Biochem Biophys Res Commun 262, 624-628.

Rees WD (2002) Manipulating the sulfur amino acid content of the early diet and its implications for long-term health. Proc Nutr Soc 61, 71-77.

Rees WD, Hay SM, Brown DS, Antipatis C \& Palmer RM (2000) Maternal protein deficiency causes hypermethylation of DNA in the livers of rat fetuses. $J$ Nutr 130, 1821-1826.

Rees WD, Hay SM, Buchan V, Antipatis C \& Palmer RM (1999) The effects of maternal protein restriction on the growth of the rat fetus and its amino acid supply. Br J Nutr 81, 243-250.

Rees WD, Hay SM, Cruickshank M, Reusens B, Remacle C, Antipatis C \& Grant G (2006) Maternal protein intake in the pregnant rat programs the insulin axis and body composition in the offspring. Metabolism 55, 642-649.

Rong N, Selhub J, Goldin BR \& Rosenberg IH (1991) Bacterially synthesized folate in rat large intestine is incorporated into host tissue folyl polyglutamates. J Nutr 121, 1955-1959.

Rowling MJ, McMullen MH, Chipman DC \& Schalinske KL (2002) Hepatic glycine $\mathrm{N}$-methyltransferase is up-regulated by excess dietary methionine in rats. $J$ Nutr 132, 2545-2550.

Sepehr E, Peace RW, Storey KB, Jee P, Lampi BJ \& Brooks SPJ (2003) Folate derived from cecal bacterial fermentation does not increase liver folate stores in 28-d folate-depleted male SpragueDawley rats. J Nutr 133, 1347-1354.

Stead LM, Brosnan JT, Brosnan ME, Vance DE \& Jacobs RL (2006) Is it time to reevaluate methyl balance in humans? Am J Clin Nutr 83, 5-10.

Torrens C, Brawley L, Anthony FW, Dance CS, Dunn R, Jackson AA, Poston L \& Hanson MA (2006) Folate supplementation during pregnancy improves offspring cardiovascular dysfunction induced by protein restriction. Hypertension 47, 982-987.

Wagner C, Briggs WT \& Cook RJ (1985) Inhibition of glycine n-methyltransferase activity by folate derivatives: implications for regulation of methyl group metabolism. Biochem Biophys Res Commun 127, 746-752.

Waterland RA \& Garza C (1999) Potential mechanisms of metabolic imprinting that lead to chronic disease. Am J Clin Nutr 69, 179-197.

Webb HK \& Matthews RG (1995) 4-Chlorothreonine is substrate, mechanistic probe, and mechanism-based inactivator of serine hydroxymethyltransferase. $J$ Biol Chem 270, 17204-17209.

Zeisel SH (2006) Choline: critical role during fetal development and dietary requirements in adults. Апnи Rev Nutr 26, 229-250.

Zeisel SH, Mar MH, Zhou Z \& da Costa KA (1995) Pregnancy and lactation are associated with diminished concentrations of choline and its metabolites in rat liver. $J$ Nutr 125, $3049-3054$. 